\title{
Bridging the rural-urban divide in social innovation transfer: the role of values
}

\author{
Imran Chowdhury ${ }^{1} \mathbb{C}$
}

Accepted: 13 July 2020 / Published online: 5 October 2020

(c) Springer Nature B.V. 2020

\begin{abstract}
This study examines the process of knowledge transfer between a pair of social enterprises, organizations that are embedded in competing social and economic logics. Drawing on a longitudinal case study of the interaction between social enterprises operating in emerging economy settings, it uncovers factors which influence the transfer of a social innovation from a dense, population-rich setting to one where beneficiaries are geographically dispersed and the costs of service delivery are correspondingly elevated. Evidence from the case study suggests that institutional bricolage- the crafting of improvised solutions in resource-constrained settings-can serve as potent driving force in driving innovation transfer, and that this process of re-combining available resources may be facilitated by the extent to which the values between partner social enterprises are aligned. With such alignment, social enterprise partners may be able to increase trust, develop a smoother knowledge-transfer process, and find practical solutions which facilitate the transfer of life-enhancing social innovations to neglected rural settings.
\end{abstract}

Keywords Social entrepreneurship · Institutional complexity $\cdot$ Institutional logics $\cdot$ Knowledge transfer $\cdot$ Partnerships · Values

\section{Introduction}

In recent years, the growth of social enterprises, which provide vital services across diverse sectors of the economy such as education, healthcare, and enterprise development, has received significant popular and academic attention. For instance, the growth of microfinance organizations, both for-profit and not-for-profit, has captured the imagination of government and non-governmental organization officials and generations of students in public policy and business schools across the world (Zhao 2014; Battilana and Dorado 2010). The rapid increase in attention to these firms reflects not only the tremendous demand for the services they provide, but also the potential for these services to reach a wider audience. In short, there is a clear and compelling case for social enterprises to "scale" their successful models and practices beyond their local area to maximize their impact on society.

Imran Chowdhury

chowdhury_imran@wheatoncollege.edu

1 Diana Davis Spencer Chair of Social Entrepreneurship, Wheaton College, Norton, MA 02766, USA
While a number of options for scaling the impact of this knowledge exist, including developing franchises or diffusing best practices via mediating bodies such as multilateral organizations, partnering with other social enterprises remains among the most popular options (Bloom and Chatterji 2009; van Wijk et al 2018). Traditional research on inter-organizational partnerships has considered the value of partnerships in gaining access to new markets and technologies, sharing knowledge, engaging in organizational learning, and developing greater levels of mutual dependence between partners (Horowitz and McGahan 2019). More recently, research on partnerships has examined organizations in a cross-sector setting (Vurro et al. 2010; Ahmadsimab and Chowdhury 2019), or in the context of public-private partnerships (Saz-Carranza and Longo 2012; Bishop and Waring 2016). In both streams of research, a focus on organizations which operate with primarily profit-maximizing or primarily social logics, has shifted in recent years to organizations where profit-making and social motivations co-exist (Greenwood et al 2011).

What these studies have not considered in depth, however, is situations in which different forms of social logics co-exist, where the rationality for generating social impact 
varies between organizations in a partnership (Friedland 2013). Social logics vary widely, and interact in distinct ways with the commercial logic. For instance, research by Peifer et al. has examined how actors navigate logics such as religion in the context of science commercialization and in the mutual fund industry (Peifer et al. 2019; Peifer 2014). In the case of religious mutual funds, organizations operating at the intersection of the competing logics of religion and finance engage in specific kinds of boundary work which leads to situations of enduring institutional complexity (Peifer 2014). Other studies have looked at social logics in terms of structural roles, for instance, farmers operating as artists in commercial wine production (Voronov et al. 2013), or social logics manifested as social welfare logics in the case of work-integration enterprises (Pache and Santos 2013) or development logics in the microfinance sector (Battilana and Dorado 2010). Partnerships between social enterprises thus offer an ideal setting for the study of these phenomena, wherein different social logics may interact with each other in addition to their interactions with the commercial logic.

Organizations operating with a multiplicity of institutional demands, or in situations of institutional complexity, have varying responses to these demands (Oliver 1991; Mars and Schau 2017; Piatti and Dwiartama 2016). When these demands conflict, as may be the case with organizations that balance social and economic goals, an organization's response may be a function of the nature of the conflicting demands or the way this conflict is dealt with by organization members (Pache and Santos 2010, 2013; Wijers 2019). This thus paper seeks to better understand partnership between social enterprises (Mair and Marti 2006) where the goal is transferring knowledge (Boxenbaum and Battilana 2005; Lounsbury 2007) for the purpose of scaling up social innovations (Bloom and Chatterji 2009).

In focusing on factors which influence the transfer of a social innovation from a dense, population-rich setting to one where beneficiaries are geographically dispersed and the costs of service delivery are correspondingly elevated, this article helps to develop a better understanding of the ways in which organizations manage relationships with partners that have different logics. Further, by examining the spiritual and social welfare logics as distinct rationalities for generating social impact (Gümüsay 2017), and the ways in which these logics may align or clash in the context of a partnership, this study may also be able to better elucidate factors which facilitate or inhibit knowledge transfer between social enterprises and other hybrid organizations. Finally, by examining innovation transfer from urban to rural areas, the article focuses on a long-neglected domain in studies of social enterprise which may have significant policy impacts (Jia and Desa 2018).

In order to address these questions I draw from a fieldworkbased case study of the transfer of affordable eye-care services from the Aravind Eye Hospitals system in India to an eye hospital in Paraguay. Evidence from this case study suggests that institutional bricolage may serve as potent force in driving innovation transfer, and that the process of re-combining available resources can be facilitated by the extent to which the values between partner social enterprises are aligned. Such alignment aided the social enterprise partners in this study to increase trust and to develop a smoother knowledge-transfer process, wherein potential areas of conflict were pre-emptively managed by focusing on points of commonality between the partner organizations. The paper makes three principal contributions. First, it provides evidence that alignment between the logics of social enterprise partners may influence the strategies firms use to transfer their knowledge while retaining the fidelity of that knowledge (Ansari et al. 2010). Second, it points to the importance of such logics alignment in facilitating the institutional bricolage (Baker and Nelson 2005; Desa 2012; Clough et al. 2019) which enables a search for practical solutions geared towards bringing a life-enhancing social innovation to neglected rural settings. The third contribution brings together the first two and points towards an enhanced understanding of how social logics can co-exist in the context of a partnership, and how they may impact broader processes of organizational efficiency and economic concerns as organizations attempt to scale their social impact beyond their local areas of operation.

The remainder of the article is organized as follows. In the next section, I offer a short overview of the literatures on institutional complexity and bricolage, concentrating in particular on how these literatures converge upon the phenomenon of innovation transfer. Subsequently, in the third section of the article, I outline the study's methods. I present the case study upon which I draw for this article, including the broader study of which it is part. I also describe the data collection and data analysis process that I undertook. In the fourth section of the article, I present the findings from this study, including the diverse social logics that were identified in the case and the ways in which the social enterprise partners managed the innovation transfer process. In the fifth, and concluding, section, I discuss the implications of these findings to the broader fields of institutions and entrepreneurial bricolage, and for the literature on "scaling" social innovations. Some practical applications of the study are also discussed for managers, consultants, and others working with social enterprises.

\section{Knowledge transfer: an institutional complexity and bricolage perspective}

Recent research in organizational theory has looked at the embeddedness of organizations in pluralistic institutional environments where multiple logics prevail, one that is 
fundamental to the world in which social enterprises operate (Mair and Marti 2006; Greenwood et al 2011; Skelcher and Smith 2014). This research builds on prior work on institutional dynamics, which tends to see institutional change as driven by changes in a single, dominant logic (Thornton and Ocasio 2008; Thorton and Ocasio 1999). While a move from a focus on dominant institutional logics to multiple, coexisting logics offers numerous opportunities to re-conceive organizations and their broader environment, a number of challenges also arise. When new institutional logics prevail in the environment, organizations tend to imitate the most successful organizations embedded in and identified with these logics. When there are multiple logics in the environment, however, organizations have greater freedom with respect to the institutional pressures that they choose to comply with. In such instances, organizations may choose to adopt and re-interpret successful practices and standards as exemplified by institutional logics by means of a process of translation (Czarniawska and Sevon 1996) or editing (Sahlin-Andersson 1996).

A plurality of institutional logics impacts upon questions of identity as well. As scholars have noted, identity plurality in organizations, often emerging from environments with different sets of norms, may lead to tensions and conflicts within organizations (Wry and York 2017; Smith et al 2014; Fiol et al. 2009). While greater attention is now being focused on multiple institutional logics and their impact on organizational fields and within organizations themselves, for the most part researchers haven't focused on how multiple logics can influence inter-organizational processes within the context of organizational hybrids such as social enterprises. This is important because the interorganizational setting allows us to see how alignment or non-alignment of logics between organizations may impact organizational processes. This setting also allows researchers to observe how organizational processes unfold and are interpreted by the parties in these interactions.

Additionally, an examination of organizational processes in social enterprises must take into account some of the fundamental mechanisms used by entrepreneurs to manage their environments and to ensure their survival. Prior work in the realm of entrepreneurship and organizational studies has discussed the importance of bricolage in actors' attempts to craft solutions to existing problems under situations of resource constraint (Baker and Nelson 2005; Lévi-Strauss 1966). In essence, by making do with the materials and structures and processes available at hand, entrepreneurs are able to overcome constraints which seemingly limit their freedom of action and ability to achieve their goals (Fisher 2012). More recently, scholars of social entrepreneurship have observed the applicability of bricolage concept in resource-constrained settings where organizations are attempting to move forward social goals and social value creation using processes and techniques borrowed from the business world (Di Domenico et al 2010; Desa 2012; Desa and Basu 2013; McDermott et al 2018; Chowdhury 2019). This research has started to bridge the institutional complexity and bricolage perspectives in the social enterprise context.

For instance, in a study of the challenges encountered by international technology social entrepreneurs, Desa (2012) finds that the conditions for resource mobilization are simultaneously enabled and constrained by the cognitive, normative, and regulative institutional pillars. Though social enterprises embedded in supportive institutional contexts more easily gain legitimacy and access to standard resources, less-embedded social entrepreneurs are freer to engage in bricolage activities that challenge the norms of existing institutional arrangements to their benefit. Relatedly, a recent study of Australian social enterprises finds that entrepreneurial bricolage proceeds differently in rural versus urban settings. While rural social enterprises made relatively greater use of financial and physical assets accessed through networks within their communities, urban social enterprises were more likely to draw on assets via corporate partnerships and structured philanthropic ventures (Barraket et al 2018).

The present study builds this prior work on institutions and bricolage in order to gain a deeper understanding of the ways in which social enterprises manage relationships with partner organizations to transfer innovations that cross the rural-to-urban divide, a domain that heretofore remains under-studied. In addition, it examines the role played by the alignment of institutional logics in facilitating innovation transfer processes. I highlight some of the principal differences for innovation transfer between the traditional commercial entrepreneurship space and the emerging social entrepreneurship space in Table 1 below.

\section{Methods}

\section{Research setting}

In order to understand how social enterprises transfer innovations from population-rich settings to rural areas with dispersed populations, I draw on a 2-year-long qualitative field study of partnerships between social enterprises in developing countries that encompasses 83 semi-structured interviews, 9 weeks of on-the-ground observations, and the examination of extensive archival material and documents including emails, meeting minutes, annual reports, project reports and updates, briefs and monographs, books written about the social enterprises being studied, consulting evaluations, and survey data. These organizations were drawn from a sample of sixteen finalist organization pairs 
Table 1 Innovation transfer in commercial entrepreneurship vs. social entrepreneurship

\begin{tabular}{lll}
\hline & Commercial entrepreneurship & Social entrepreneurship \\
\hline Economic motivation & Maximize & Satisfice \\
Social motivation & Satisfice & Maximize \\
Incentives & Capturing value & Creating value \\
Who are the principals? & Shareholders, managers & Local community, populations neglected by market and govern- \\
& & ment \\
What is delivered to principals? & Economic benefits (profits) & Social impact, social recognition \\
Context of transfer & Regulatory frameworks (e.g., tax and & Normative and cognitive frameworks, sociopolitical environment, \\
& legal), macroeconomy, sociopolitical & macroeconomy (with decreased salience of market-selection \\
& environment & mechanisms) \\
\hline
\end{tabular}

from the proposal submission process to a well-known European Foundation. Organizations submitted proposals jointly (generally in pairs) in the hopes of receiving funding for the transfer of a social innovation between a source and target organization.

Five winning proposals were selected from the sixteen finalist proposals which submitted applications, and I had access to the full proposals of all these organizations. The applications were a rich source of information regarding the organizations, the innovation being transferred, and the expected parameters and scope of their partnerships. I also had access to the full list of applicants and letters of interest for the competition, and administered a survey to all 16 finalist source organizations (with 15 responses) to capture information on their social innovations and their past, extant, and future knowledge transfer partnerships. Subsequently I completed field visits to four of the five winning sets of organizations (the fifth set of visits was not undertaken due to logistical and financial constraints), starting with a pilot study between a pair of Indian social enterprises. The bulk of interviews, observations, and archival material and documents were collected during these field visits. Further details regarding the data collection process for the full study are included in Table 2.

\section{Sampling procedure}

From the full sample of organizational partnerships described above, I selected a set of three social enterprises that had partnered for the purpose of transferring a system of affordable eye-care services. I specially chose this partnership for further study for two reasons. First, the innovation transferred was in the domain of healthcare within developing countries, a domain with broad potential implications in a broad range of geographies facing resource constraints. Prior research in both urban and rural settings has pointed to the importance of health-focused social enterprises in delivering care to a range of disadvantaged communities (Nirmalan et al. 2004; James 2014; Chowdhury 2015; McNamara et al. 2018). Second, I selected this set of organizations as the eye care system transferred by the source organization can be configured for a range of different health care environments across different geographic regions, in particular in resource-constrained emerging (developing) economy settings. Due to the relatively repetitive nature of the refraction

Table 2 Data collection process

\begin{tabular}{|c|c|c|}
\hline Stage & Name & Description \\
\hline 1 & Preliminary survey and site selection & $\begin{array}{l}\text { Short survey was sent out to the } 16 \text { finalist organizational pairs; } 15 \text { completed the survey. Data } \\
\text { from surveys used to construct a list of the four most promising organizational pairs for follow- } \\
\text { up }\end{array}$ \\
\hline 2 & Pilot study & $\begin{array}{l}\text { An initial case study was conducted on-site at one pair of source and target organization partners, } \\
\text { both located in India, to gain insight into the social innovation transfer process. This pilot study } \\
\text { allowed the "field-testing" of interview protocol which was refined for use subsequent data- } \\
\text { gathering }\end{array}$ \\
\hline 3 & Field visits and interviews & $\begin{array}{l}\text { Researcher visited source and target social enterprises in the } 3 \text { remaining partnerships, located in } \\
\text { Bangladesh, India, Paraguay, and Sri Lanka }\end{array}$ \\
\hline 4 & Follow-up and data analysis & $\begin{array}{l}\text { Following and concurrent to field data collection I gathered updates on the progress of the } \\
\text { knowledge transfer processes via email exchanges and telephone calls. I also had access to the } \\
\text { periodic updates sent by each pair of organizations to the funding agency, up to and including } \\
\text { the final reports. Subsequently, final phone calls with both source and target organizations were } \\
\text { conducted }\end{array}$ \\
\hline
\end{tabular}


techniques, examination procedures, cataract surgeries, and administrative and support operations associated with the system, it can potentially be deployed across a range of settings with varying endowments of local resources. This contextual modularity may thus have important practical considerations for the eye care setting and, more broadly, the public health domain as well.

As noted above, the organizations I focused on in this study included one source (transferring knowledge) organization and one primary target (receiving knowledge), and operated within the field of eye-care services and ophthalmology. In addition, the given the greatly varied geographical scope (dense population vs. dispersed, rural population) between the source and target organizations, a third (local) partner joined the organization to help with the implementation of the social innovation (see Fig. 1 below). The transferring organization, the Aravind Eye Hospital (Aravind) is located in Madurai, India and has been working since 1976 to eliminate needless blindness by providing comprehensive eye care services to the poor. Its technology has allowed millions of poor people to work, support their families, and lead fuller, more productive lives. One of the most productive eye care facilities in the world, Aravind has reached impressive scale; in 2017-2018 it recorded nearly 4.2 million outpatient visits, and performed over 478,000 surgeries. Of these surgeries, nearly $49 \%$ were delivered free of charge to the patient. Aravind also has proven methodology for transferring its model to other eye care providers in developing countries through the Lions Aravind Institute of Community Ophthalmology (LAICO). This system was being transferred via the partnership examined in this article:

Designing services—both range and the volume, based on the community need is the key for an effective eye care program. Aravind, through LAICO tries to design services based on community need by sharing its model of high volume, high quality and affordable eye care through structured Consultancy \& Capacity building processes. This starts with gap analysis to facili- tate eye care programs, developing a good strategic plan, and providing need-based assistance during plan implementation. This process is based on four core principles in eye care-Demand generation, Resource utilization, Quality of services, and becoming Financially viable. Over a period of time, Fundación Visión will become a similar resource center for hospitals from Latin and South American countries.

The receiving, or target, organization was Fundación Visión. Founded in 1992, this hospital system is the leader in blindness prevention in Paraguay, and operates a 6000 $\mathrm{m}^{2}$ hospital in in central Asuncion, the capital of Paraguay. Fundación Visión is the only institution in the country that provides regular monthly ophthalmologist care in rural areas of the country and trains "eye health promoters" to seek out persons in need of treatment for blindness and other eye problems. The partnership with Aravind was undertaken so that Fundación Visión could increase the "quality, volume and sustainability of the eye care services" and improve the quality of its ophthalmology training programs.

At the same time, Fundación Visión also wished to increase the options for financing of eye care procedures in Paraguay, and, despite a strong in-country network of clinics, was constrained in its ability to reach the most remote parts of the country. Paraguay is country with relatively low population density of about 15 people per square kilometer (versus 416 per square kilometer in India), and outside of its four largest cities (Asuncion, Ciudad del Este, San Lorenzo, Capiata) and surrounding areas much of the population lives in small towns and villages that are very dispersed. As a result, it partnered with Fundación Paraguaya, one of the leading microfinance providers in Paraguay, to gain access to its deep network of offices and broad contacts with the rural poor in the most remote parts of Paraguay, and also to access the organization's expertise in finance to help patients pay for what could be very expensive surgeries. Founded in 1985, Fundación Paraguaya generates most of its revenue through its microfinance operations, but is also involved in
Fig. 1 Source social enterprise, target social enterprise, and local partner

\section{Source Social Enterprise $\quad$ Target Social Enterprise Local Partner}

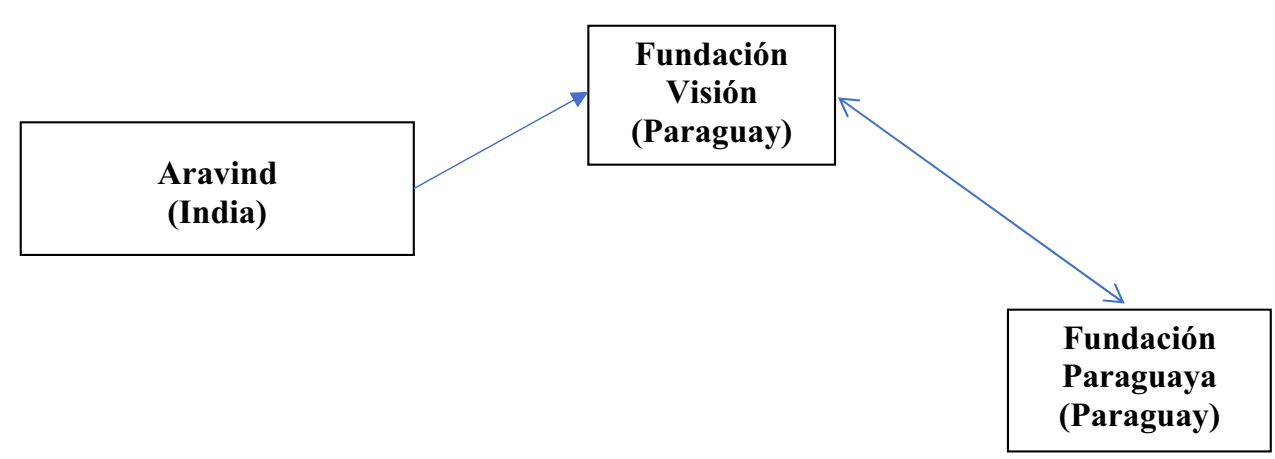


other operations such as the Junior Achievement program and an agricultural school for youth which teach the values of entrepreneurship throughout Paraguay and beyond.

\section{Data collection}

This study uses four data sources: (1) semi-structured interviews; (2) field observations; (3) results from a preliminary survey of the partner organizations; and (4) archival data and documents. The primary source is semi-structured interviews with individual respondents. A total of 32 individual interviews were conducted. These interviews were conducted in-person in India and Paraguay with senior managers and program implementation and monitoring staff at Aravind (11 interviews), Fundación Visión (10 interviews), and Fundación Paraguaya (11 interviews). Interview questions focused on the innovation being transferred, the focal organization's history, operations and objectives, and the dynamics of the partnership being examined (see Appendix for full list of questions). The interviews were recorded and transcribed, and I took extensive field notes during the course of my site visits to each of the three organizations. Interviews and notes were transcribed and summarized within $24 \mathrm{~h}$ of the interview's completion. Table 3 provides further information regarding the interviews.

I supplemented my interview findings with field observation, including visits to field offices, screening camps, and project sites. I jotted notes on a paper pad during these visits, including notes from discussions with beneficiaries and local staff going about these work. These notes were later re-written into the field journal I kept on my laptop computer, and served as an important means for me to triangulate data obtained from in-person interviews and from company documents. Finally, as part of my collection of archival material and documents at Aravind, Fundación Visión, and Fundación Paraguaya, I was able to access both publiclyavailable and internal organizational records. These included emails, meeting minutes, annual reports, project reports and updates, briefs, monographs, and consulting evaluations.

\section{Data analysis}

As befits the exploratory nature of this study, no testable hypotheses were formed prior to data collection (Glaser and Strauss 1967). Rather, the goal of the study to use the data collected to develop specific theoretical constructs and related propositions which advance current theory in novel directions (Suddaby 2006). This approach is particularly suitable for studies of social entrepreneurship and bricolage as it allows the development of concepts in close connection to previous theorizing, important given the dearth of prior empirical work at the intersection of these two fields (Miles and Huberman 1994). The data was analyzed iteratively,
Table 3 Description of Informants

\begin{tabular}{|c|c|}
\hline Organization & Formal position \\
\hline Aravind & $\begin{array}{l}\text { Faculty associate (training) } \\
\text { Managing director (Aurolab) } \\
\text { Executive director (LAICO) } \\
\text { Administrator } \\
\text { Administrator-LAICO } \\
\text { Faculty./senior manager } \\
\text { Assistant Manager (Field Services) } \\
\text { Head ophthalmologist } \\
\text { Medical resident (1st year) } \\
\text { Assistant administrator (Theni Hospital) } \\
\text { Chief medical officer (Theni Hospital) }\end{array}$ \\
\hline Fundación Visión & $\begin{array}{l}\text { Coordinator, mobile visión camps (Asuncíon) } \\
\text { Medical resident (2nd year) } \\
\text { Medical resident (3rd year) } \\
\text { Director of operations } \\
\text { Manager, IT and purchasing } \\
\text { Clinic coordinator } \\
\text { Manager, social work } \\
\text { Manager's assistant (administration and } \\
\text { finance) } \\
\text { Manager, administration and finance } \\
\text { Medical director }\end{array}$ \\
\hline Fundación Paraguaya & $\begin{array}{l}\text { General manager, Fundación Paraguaya } \\
\text { Director of operations } \\
\text { Microfinance coordinator } \\
\text { Director of planning } \\
\text { Director, Paraguani (branch office) } \\
\text { Director, Itá (branch office) } \\
\text { Director, Mariano Roque Alonso (branch } \\
\text { office) } \\
\text { Microcredit Group Manager, Mariano Roque } \\
\text { Alonso (branch office) } \\
\text { Director, agricultural school } \\
\text { Director, regional microcredit offices } \\
\text { (Asuncíon) } \\
\text { Director, business development }\end{array}$ \\
\hline
\end{tabular}

followed the principles of open-ended, inductive theory building, as I kept going back and forth between theory development and empirical data analysis. I worked between interviews, field notes, company documents, archival records, and relevant literature to develop themes and codes in order to categorize findings related to the management of partnerships by social enterprises, including the impact of institutional logics and their alignment (or non-alignment) on organizational processes.

The principal unit of analysis for understanding the impact of institutional complexity (Greenwood et al. 2011) on the innovation transfer partnership between Aravind and its collaborators in Paraguay, Fundación Visión and 
Fundación Paraguaya. I attempted to make sense of the data using "temporal bracketing," in line with recommendations from Langley (1999). For the sake of clarity, I present the three steps of data analysis in greater detail below, and in summary form in Table 4.

\section{Step one: identifying key moments in the partnership}

In the first step of analysis, I identified key moments in the partnership, including partnership formation and development. By extracting a chronology of events for each case in this manner, I was able to develop narratives documenting how the interactions between Aravind and Fundación Visión and Fundación Visión and Fundación Paraguaya evolved as the tri-partite collaboration developed.

\section{Step two: coding institutional logics and key interactions}

During the second stage of data analysis, I coded and compared moments in the partnerships which were associated with the social and commercial logics, the initial theoretical frame drawn from the institutional complexity literature I used to guide my analysis, cycling iteratively between data and emerging concepts related to the tensions in both cases (Suddaby 2006). What I found was that the simple "social" logic was insufficient to explain what was going on. Rather, it became clear that the social logic was actually manifesting as distinct spiritual logic and social welfare logics. Whereas the social welfare logic obtains legitimacy by making products and delivering services to address local social needs, the spiritual logic obtains legitimacy by linking the provision of social services and goods to an association with deities and faith as its fundamental guiding mechanism (Pache and Santos 2013; Gümüsay 2017). These spiritual and social welfare logics, along with the commercial logic, became the organizing frame for my understanding of the interactions between the social enterprises in this study.

Subsequently, I used "pattern matching" (Miles and Huberman 1994) to categorize the interactions between the based on the dominant institutional logic at play: (1) spiritual logic; (2) social welfare logic; and (3) commercial logic. These categories were derived from my data and existing theory (Gümüsay 2017; Pache and Santos 2013), and I attempted to identify how the three social enterprises dealt with alignment or non-alignment of logics by examining themes in the interviewees' comments. I found that senior executives, mid-level managers, and front-line employees at all three organizations identified tensions in their relationships, but at the same time a subset of these individuals identified specific ways in which these tensions were dealt with in order to advance the innovation transfer process.

\section{Step three: tying together logics, interactions, and emerging constructs}

My third step was to tie the emergent spiritual logic, the social welfare logic, and the economic logic to the interactions between the three organizations in the innovation transfer partnership examined in this study. This was not a linear process. Rather, my analysis proceeded recursively (Pratt 2009; Langley 1999) until I had a grasp of the emerging constructs related to the management of the operations of the partnership. Codes consisting of several of the primary constructs of entrepreneurial bricolage (e.g., seeking resources, "making do", avoiding challenges) were used to capture the operations and activities used by the social enterprises in this study to negotiate the alignment or non-alignment of logics and the worldviews which influenced them. Additionally, I identified one important emergent conceptual category, or mechanism, used by Aravind and Fundación Visión to ensure the impact of Aravind's model as it was transferred from India to Paraguay, and also identified sources of tension that emerged in the course of the innovation transfer process. These constructs and interactions are outlined in detail below.

Table 4 Data analysis steps

\begin{tabular}{lll}
\hline Step & Name & Outcomes identified \\
\hline $1 \quad$ Identifying key moments in the partnership & $\begin{array}{l}\text { (1) Partnership formation } \\
\text { (2) Partnership development }\end{array}$ \\
& $\begin{array}{l}\text { (3) Narratives around partnership maintenance } \\
\text { Coding institutional logics and key interactions }\end{array}$ \\
$\begin{array}{l}\text { (1) Identifying three dominant institutional logics: spiritual, social welfare, and economic } \\
\text { (2) Describing points of tension in partnership related to logics non-alignment or align- } \\
\text { ment }\end{array}$ \\
$\begin{array}{ll}\text { ing constructs } & \text { (1) identifying entrepreneurial bricolage processes (e.g., seeking resources, "making do", } \\
\text { avoiding challenges) } & \text { (2) Innovation fidelity: developing and defining the construct }\end{array}$ \\
\hline
\end{tabular}




\section{Findings}

Prior work on multiple or conflicting logics in organizations has highlighted the role of a dominant logic or competing logics in guiding or constraining organizational action (Pache and Santos 2013; Battilana and Dorado 2010). This study points to broader and richer sets of logics which prior work has not systematically considered. For instance, I found that social enterprises are not uniformly impacted by one or two dominant logics of action (e.g., a social logic and an economic logic). Rather, a rich set of logics, multiple in nature, impact their actions. While other scholars have focused on social and economic logics in the past, only recently has research started to examine how spiritual logics can guide the actions of enterprises (Gümüsay et al 2019; Gümüsay 2017; Tracey 2012). My research attempts to characterize how the values linked to a spiritual logic are manifested not only within the focal organization (Friedland 2013), but also how they link to inter-organizational interactions (Ahmadsimab and Chowdhury 2019; Vurro et al 2010) with partner organizations in the innovation transfer context.

Transfers of innovations between social enterprise partners offer a unique setting for studying institutional complexity. I found that logics may channel and guide the process of innovation transfer by impacting micro-processes of transfer as they are enacted at the organizational level by social enterprises, including the role played by institutional bricolage in this process (Baker and Nelson 2005; Desa 2012). Specifically, different social logics and the commercial logic impact the ways in which social enterprises incorporate different practices and innovations from partners, the solutions they craft to "make do" with the resources at their disposal, and the nature of the conflicts they encounter in the course of their partnerships. This, in turn, impacts the potential for "scaling" social innovations beyond the focal organization in which it was developed. These findings are discussed in detail in the sections which follow.

\section{Organizations' commitment to multiple logics}

Recent work (Battilana and Lee 2014; Ebrahim et al. 2014) has examined the conditions that encourage the persistence of multiple logics in a field, in particular when the organizations contained within the field are characterized by hybridity. Among the factors proposed are multiple local contexts for practice diffusion (and thereby local adaptation) and the lack of a dominant, overarching regulatory or professional framework that is able to impose field-level standards. Both these factors exist in varying degrees for the organizations examined in this paper. As a result, the actions of organizational actors in this study seem to be influenced by multiple logics, including one which has only recently been characterized in the institutions literature. At the level of social logics, I found the most variation between the organizations. For, Aravind and Fundación Visión, I identified an underlying "spiritual logic" rooted in their own organizations' histories which, in turn, influenced their social logic. For Fundación Paraguaya, the social welfare logic aligned with the economic logic, in line with prior work on microfinance organizations (Zhao 2014; Jia et al 2015). Below, I discuss on findings related to these logics in detail, highlighting both points of convergence and divergence for the three organizations in this study. Table 5 characterizes the spiritual, social welfare, and economic logics in summary fashion.

\section{Spiritual logic}

I found that Aravind, and Fundación Visión were guided by a core spiritual logic in their actions. This was in addition to the social logic common to all organizations in this study. Aravind is a pioneer in the provision of comprehensive eye care services to the poor. Its late founder, Dr. G. Venkataswamy, was fifty-eight years old and recently retired from the Indian civil service when he started the organization as an 11-bed hospital founded in a private residence in 1976. Dr. Venkataswamy_or "Dr. V." as he was affectionately known - was inspired by the teachings of Sri Aurobindo, one of the leading Hindu sages of southern India. This spiritual

Table 5 Comparison of spiritual, social welfare, and economic logics

\begin{tabular}{llll}
\hline Characteristic & Spiritual logic & Social welfare logic & Economic logic \\
\hline Goals & $\begin{array}{c}\text { Relieve suffering of beneficiaries while } \\
\text { adhering to core religious principles }\end{array}$ & $\begin{array}{c}\text { Deliver services and produce products } \\
\text { to address local social needs }\end{array}$ & $\begin{array}{c}\text { Maximize surplus revenue through } \\
\text { efficiency of operations }\end{array}$ \\
Target population & $\begin{array}{c}\text { Beneficiaries to be served, particularly } \\
\text { the poor and marginalized }\end{array}$ & $\begin{array}{c}\text { Beneficiaries to be served, particularly } \\
\text { those who are seen as more or less } \\
\text { "deserving" of "support" }\end{array}$ & $\begin{array}{c}\text { Clients to be served with a focus } \\
\text { on efficiency and on generating } \\
\text { demand for future interventions }\end{array}$ \\
Operational principles & $\begin{array}{c}\text { Design interventions to serve benefi- } \\
\text { ciaries, to relieve beneficiaries' suf- } \\
\text { fering, and to serve a "higher power" }\end{array}$ & $\begin{array}{c}\text { Design interventions to maximize } \\
\text { impact of available funds on social } \\
\text { impact and positive social outcomes }\end{array}$ & $\begin{array}{c}\text { Maximize surplus revenue through } \\
\text { efficiency of operations and } \\
\text { demand generation }\end{array}$ \\
\hline
\end{tabular}

This table is based on Pache and Santos (2013) and Gümüsay (2017), and on interviews and other data collected for this study 
commitment is a core guiding principle of the organization, this philosophy was clearly reflected in Dr. V.'s writings and in the interviews that he gave. Some of these words are quoted each year in Aravind's annual reports. One of the clearest statements of the link between Aravind's spiritual roots and its activities is found on the third page of the 2008 Annual Report, which quotes Dr. V.:

Our effort is to make Aravind an instrument of the Divine Will. We strive to forget our limitations and work with the direction of the Divine Will, not in a vain superficial way but with a deep commitment and faith that guidance comes from a higher level of consciousness. Then one is able to work with the great confidence that comes only with that faith and realization that we are all part of a spiritual capacity or spiritual power. It is then that all of nature works with you. You don't feel that you are a superior being but you are an instrument in the hands of a higher force and it is in that spirit that we meet our day to day struggles and successes.

More recently, in the 2018 annual report, Dr. V.'s words are again used to reflect the importance of the Divine, especially as reflected in Hindu philosophy, in Aravind's work:

The Bhagavad Gita became popular and people started reading it to understand Kharma yoga. I remember well reading it in those days. At the same time Swami Vivekananda became very popular with us. His speeches were so powerful and inspiring, they made me look forward to doing something challenging and great.

I also read the teachings of Sri Ramakrishna Paramahamsa, who had very little schooling, but who had known God in person. All these contacts influenced our thinking in those days. We were not thinking of amassing money as our goal in life. We always aspired to some perfection in our lives, like the realization of God, or reaching of higher level consciousness in Yoga.

This organization-level commitment is manifest in the daily operations of the organization, and influences the actions of organizational members. For instance, the Chief Medical Officer of an Aravind district hospital similarly referenced a "higher power" guiding the organization:

... I don't know whether you believe it or not, but in this part of country, and on the Indian subcontinent, I think it's believed everywhere, that we are instruments only. Somebody else has decided that what I should do. Whatever we are doing, I don't think it's our effort only. Many people put the same amount of effort or more, but they don't achieve that. Somebody wants us to do that much, so we are able to do it. Whatever we are doing, that divine force is there, a higher power is pushing us.

Similarly, Fundación Visión displayed a commitment to Christian principles in its work:

Our mission is "to be a leading institution in the prevention of blindness, in the promotion of ocular health and in the delivery of high-quality services, as well as in the training of new professionals for community health." The work of the organization rests on Christian principles and relies on the Bible as the sufficient rule of faith and conduct. (Fundación Visión web site; accessed: 30 May 2018).

This commitment to a Christian God was confirmed by the physician who served as the Director of Operations at Fundación Visión, who noted how its influence extended to the care and treatment of patients at the organization:

FV is also a Christian organization. Dr. Reinhold started in a loaned operating theatre in another hospital; he was driven by his Christian values to do this. FV now has 6000 patients per year, and the result of the care that they receive here means that patients can have a better life with God. The way we interact with patients is the way God or Jesus would act with patients. The staff are devoted to the patients.

Parboteeah et al. (2009) have noted that religion has a strong norm-setting influence with respect to work, which is seen as an obligation to society. In this way religion creates important work expectations for individuals, expectations which grow stronger when this work is situated in religious contextual environments. Within these two hospital systems spiritual values were an integral part of the work environment. This was manifested not just in the statements of organizational members and in official documents, but also in the physical symbols and objects which reinforced these values within these organizations. For instance, statues and pictures of Sri Aurobindo are found in the main entrance of all the major buildings within the Aravind system that I visited. The spiritual logic is important in this context as it helps to create a sense of common purpose and unity not just within the organization itself and between organizational members, but also between other organizations which share the same or similar values.

The spiritual logic also informed the way actors at Aravind and Fundación Visión approached their tasks within the health care realm, with their patients, and with respect to their interactions with members of other organizations. Aravind's Executive Director saw this connection in terms of spirituality and purpose - though Aravind is named after and inspired by the teachings of a Hindu sage and Fundación 
Visión is inspired by Christian teachings-as a point of commonality to build upon, one that would help overcome differences in "detail" and level of maturity between the two organizations:

At some level they [Fundación Visión] and Aravind share the same foundational mission. At one level there is similarity in terms of the purpose and the leadership orientation and those kinds of things, a lot of similarity. For instance, we are both in some way fundamentally committed to some higher values, you know? We are inspired by the teachings of Sri Aurobindo, and they have a lot of connection to the Christian church. Some of the difference is more on the detail, I think we probably have a lot of alignment than they have within the organization. And I think they are -- they are not very young but they probably have a lot more maturing to go through in terms of systems and processes and all of that.

\section{Social welfare logic}

At Fundación Paraguaya, the social welfare logic, rather than a spiritual logic, informed decision-making vis-à-vis the social impact of the organization's activities. This set Fundación Paraguaya apart from Fundación Visión, its incountry partner, and led to tensions in the relationship which were primarily manifested as clashes around the economic logic as outlined below. The social welfare logic at Fundación Paraguaya was structured around providing products, services, and support to address local social needs. As detailed in Table 5, in terms of target populations served what separated the social welfare logic from the spiritual logic was the former's emphasis on identifying those who were more "deserving" of support. For instance, one of my main interlocuters at the Fundación Paraguaya head office told me that while the main focus of the organization was "social," it was nevertheless focused on "selecting people for success" using different criteria took into account loan recipients' ability to "help themselves" and to build and grow successful businesses (my field notes).

Similarly, at one of Fundación Paraguaya's branch offices, the local manager told me that his field officers visited potential clients' homes to determine their level of cleanliness, the orderliness of their living conditions, and the general level of progress and order in their lives (my field notes). These criteria were seen as important determinants of individuals' worthiness for different social and credit programs. In this sense, the social welfare logic is more tightly coupled to the economic logic than a spiritual logic, which seeks to help the poor and marginalized without taking into account who might or might not be more deserving based on economic potential (though presumably there might be a bias towards those who show more devotion or faithfulness). For Fundación Paraguaya, the social welfare logic fed directly into the economic resources derived from an organization's various activities, including micro-financing of business opportunities and selling various services and products, and thus provided a framework for the operational principles need for the organization to achieve its goals (Pache and Santos 2013).

\section{Economic logic}

Beyond the spiritual and social welfare logics logic, and consistent with theory in social entrepreneurship, the economic logic was embedded in the necessities of the sector in which the organizations operated, and were related to issues of operational efficiency and demand generation for the services that they provide (Battilana and Lee 2014). In addition, Fundación Paraguaya had a "strong" form of this economic logic impacting its actions, whereas Fundación Visión had a "weak" form. Aravind's economic logic strength was somewhere in-between as the organization focused heavily on efficiency, but was at the same time foundationally committed to the idea of serving a "higher power" in serving patients, especially the ones least able to pay.

My point of departure from prior work is in the way in which I found that economic logics and the spiritual and social welfare logics mentioned above interacted in the inter-organizational setting. Where differences appeared in the interactions between the organizations in this study was at the level of the strength of the economic logic, which was more closely aligned with the social welfare logic. Specifically, even when there was no alignment between the strength of the economic logic (e.g., medium-weak in the case of Aravind-Fundación Visión), clashes at the level of operations related to the partnership were muted due to alignment on the spiritual logic aspect. However, a mismatch between the strength of the economic logic between Fundación Visión and Fundación Paraguaya (i.e., weak-strong) exacerbated already existing tensions at the level of social logic, where the lack of alignment between the spiritual logic and the social welfare logic meant that there was no means to diminish tensions between the organizations.

In prior work on social enterprises, the economic logic has been found to counterbalance the social welfare logic and focus organizations on questions such as demand generation and efficiency (Pache and Santos 2013; Battilana and Dorado 2010). In this study, the economic logic differed in strength across companies-for Fundación Paraguay, primarily a microfinance organization, it was a major driving force; for Fundación Paraguay it was far less important or even de-emphasized; for Aravind, social and spiritual commitments were balanced with a focus on delivering services efficiently. This focus on operational efficiency, as much as 
any spiritual element, was considered by Aravind's Executive Director as the fundamental pre-requisite for transferring knowledge to partners:

I think most essential [element of the Aravind model to be transferred] is the mindset. Because I think the process... you can say one thing is more important than the other. For a given hospital something can be more important than the other, you know, like certain hospitals they could be already having a tremendous number of patients, you know, but then their conversion rate, they are having very low acceptance or so there we do not focus too much on marketing, you know, that will be institution-specific.

But fundamentally the most important thing is the mindset, how they start thinking.... the market focus, customer focus, all of that... wanting to become efficiency focused or wanting to become self-supporting. You know, if you are always having the mindset that you can always raise money, you are never going to become efficient.

This efficiency focus was mirrored at Fundación Paraguaya, but in the opposite direction: the company's deep social and community connections were seen as its "differentiating" factor against versus other microfinance operators in Paraguay. Here, the emphasis was on the business or economic side, and the company's social programs-such as its agricultural school for disadvantaged but entrepreneurial young Paraguayans-fed into its money-making microcredit initiatives. The company's Director of Planning noted:

We see our programs as separate in budgetary financial terms, but they are integrated at the operational level. The principles of how to run a sound microfinance program are the same principles that we used to run the agriculture school, we used the Junior Achievement team methodology to teach entrepreneurship at the agriculture school. The agriculture school takes the sons and daughters of microfinance clients as their students, and the microfinance program gives graduates of the agriculture school lines of credit...

On the other hand, for staff at Fundación Visión, the social service of their business was paramount, even for staff at the operational rather than executive level. For instance, the manager of information technology noted to me that patient care and the spiritual side were the key drivers of the organization. The coordinator of one of the clinics at the base hospital said that the focus on caring for patients was what separated Fundación Visión from other hospitals and clinics in Paraguay. Finally, the organization's manager of social work noted that Fundación Visión is committed to its patients both inside and outside of the hospital setting. This stemmed, she felt, from its foundation in "Christian values": Fundación Visión was deeply involved in charity for patients; it is not a business, like so many other eye clinics and hospitals in Paraguay.

\section{Multiple logics and bricolage}

That a spiritual logic was found at Aravind and Fundación Visión is noteworthy, but unsurprising given the preponderance of faith-based organizations working on health and development issues. What is interesting, however, is how organization-level action can be influenced and guided by such spiritual values. My case data suggest that Aravind and Fundación Visión developed emergent strategies to ensure that their business models and innovations got scaled up. These strategies are deeply rooted in not only the process of scaling, but also the way different institutional logics at the source and target enterprise interact, and the extent to which the logics of the source enterprise and the target enterprises are aligned. They are also tied to what prior work has called "making do" with resources available in the local environment, or entrepreneurial bricolage (Desa and Basu 2013; Durand et al. 2013; Desa 2012; Baker and Nelson 2005).

\section{Maintaining innovation fidelity}

For instance, my case data indicate that the source social enterprises may be able to actively manage their partners using inter-related strategies related to the underlying balance between multiple institutional logics. These tactics can be broadly organized into one major process: maintaining innovation fidelity. In other words, the source enterprise, Aravind in this case, attempts to maintain the fidelity of their original model or innovation at the target site to preserve the intended social impact. They achieve this goal through a number of tactics, including bargaining with managers at the target organization to adopt practices and techniques developed by the source entrepreneur to ensure that the success of the original model and innovation in its new locale.

As described below, the process of maintaining innovation fidelity is related to separate aspects of the social enterprises' indirect ability to influence other organizations. This process enables source organizations with limited resources and a constrained direct ability to control of their partners' actions to exercise significant influence despite the absence of an ownership stake or even a principal-agent relationship at the target organization (Ansari et al. 2010). For Aravind, a primary way to ensure that the impact of the knowledge transferred was maintained was to induce adherence to the fidelity of their inter-linked eye care management methodology and practices (see "Methods" section for detailed description of the social innovation being transferred). Thus, their focus was on maintaining basic operating principles which could be shared 
with Fundación Visión and which would allow their system to transfer over to Paraguay.

Several Aravind managers commented to me about these principles, including the importance of starting the day early and keeping a focus on being organized to do good work. This was true of staff members both at headquarters (e.g., at LAICO, the Lions Aravind Institute of Community Ophthalmology, Aravind's training arm, and at the Madurai base hospital) and in field locations. For instance, a Faculty member at LAICO commented:

... we are trying to share principles, you know, it may not be exactly that you can replicate all our procedures but the principles can always be replicated anywhere ... for example, I will tell you, we start everyday at 7 o'clock, $7 \mathrm{AM}$ in the operating theatre, 7:30 AM in the out-patient department.... We don't say, you also should start at 7, if you start at 7 well and good, but not necessary. You can start at 8 o'clock, 8:30, 9 o'clock, fine... but how you start is what's important, how you are organized to do good work.... in the places where it is possible we suggest that they should start little early or something... Fundación Visión , time is not a problem for them, they start early.

At the Theni field hospital, the Medical Director made a similar comment:

... we follow certain principles, the basic principle on with the hospital Aravind Eye care to ensure those things. For instance, like discipline. We start 7:30 in the morning... Whatever we have committed has to be honored. It's written that at 7:30 the hospital starts, and a patient coming at 7:30 should be able to see it.

For Aravind, at the root of transferring technical procedures related to information technology, patient management, and community engagement is a focus on developing values which help organizations improve in each of these areas. This was the feeling of Fundación Visión's Chief Operating Officer as well:

Aravind helps us to improve our procedures and improve the way we are attending the community. They are helping us to improve the attention we give to our patients, and they are telling us to correct some procedures, so we can have a better flow of patients or we can attend more volumes. So they are helping us technically but they are also saying that we have to develop our values, and our discipline too. So they are saying we have to do both.

\section{Logic mis-alignment and conflict}

While aligned spiritual logics were a source of partnership strength for Aravind and Fundación Visión, the mis-aligned spiritual and social welfare logics were a source of conflict between Fundación Visión and Fundación Paraguaya. These difficulties arose as Fundación Visión sought to work with Fundación Paraguaya to fully implement one aspect of Aravind's model: demand generation for eye care services through screening camps. At these camps, patients are screened for cataract and other diseases, and those that are identified as needing follow-up treatment are referred for further follow-up. In southern India, with its great population density even at the village level, Aravind is able to use these camps to generate a constant flow of patients to its base and district hospitals. In Paraguay, with a much more dispersed population, this level of demand generation was not possible. Rather, camps have to be set up in the most rural locations to find potential patients.

This situation provided an opportunity for institutional bricolage (Desa 2012; Clough et al. 2019). While Fundación Visión had its own infrastructure in place for performing this screening function prior to the collaboration with Aravind, they did not have the reach of Fundación Paraguaya, which offers its microfinance and related products in the most remote regions of Paraguay. Facing resource constraints which did not allow it to operate these camps regularly beyond the major urban centers of Paraguay, Fundación Visión thus entered into partnership with Fundación Paraguaya to access its network of contacts across the country. Thus, Fundación Visión "made do" with the resources at their disposal (Desa and Basu 2013; Baker and Nelson 2005) by reaching potential patients needing cataract surgery and other services in rural areas where Fundación Paraguaya was able to use its resources to perform vision screenings for its customers and other community members.

However, this use of Fundación Paraguaya's network by Fundación Visión also led to conflict between the organizations. In particular, Fundación Paraguaya's staff felt that Fundación Visión was not concerned enough about promoting financing of different surgeries for patients screened at these camps. They felt that these surgeries would have been a "win-win" in the sense that Fundcion Vision would earn revenue from performing them, and Fundación Paraguaya would earn revenue by financing the operations. In addition, staff at Fundación Paraguay felt that Fundación Visión should have been more flexible about having more camps, by working in closer coordination the two organizations could build a future cataract surgery and eye care financing business in Paraguay.

The conflict which emerged between Fundación Paraguaya felt that Fundación Visión vis-à-vis the vision camps and associated promotion of financing options can be tied to the mis-alignment between the social welfare logic and "strong" form of the commercial logic at Fundación Paraguaya and the spiritual logic and "weak" commercial logic at Fundación Visión. In this sense, tensions which emerged between the two organizations mirror issues encountered 
by social enterprise partners where values and identities are mis-aligned (Chowdhury and Santos 2010; Smith et al. 2014). This finding relates to recent work by Arjaliès and Durand (2019), which suggests that values are embedded in the choices made by market actors in choosing investment product categories such as socially responsible investment funds, and that tensions may arise when there is a mis-match between the normative values of producers and consumers. Similarly, Chowdhury and Santos (2010) discuss a case wherein differing approaches to "social impact" between two partnering social enterprises, a kind of mis-alignment, led to difficulties in the transfer process and to a partial failure of the collaboration.

\section{Logics alignment and muted cultural differences}

Finally, and quite interestingly, the impact of cultural differences on the innovation transfer process was relatively muted compared to the institutional factors discussed above. Instead, what I found was that organizations tended to refer to geographic differences only with respect to actual or potential pitfalls in the transfer process; otherwise, the issue was for the most part in the background. This finding tended to go counter to expectations, as I assumed that cultural differences would be greatest when the members of the sourcetarget pair were located in different countries, and especially where the "cultural difference" between the organizations' home countries was greatest-i.e., between India and Paraguay in the case of Aravind and Fundación Visión.

However, in the case of Aravind and Fundación Visión, which are located nearly ten thousand miles $(16,000 \mathrm{~km})$ apart, geographic separation provided an opportunity rather than a barrier for transfer, according to Aravind's Executive Director:

I saw an opportunity to create synergy because Latin America is a place where there isn't any place to just do high volume affordable care. I think it is largely a mindset kind of a thing, their models are very heavily driven by the US model. So they practice very expensive medicine, which benefits $2 \%$ of the population, and a vast majority cannot afford that price. So, but this guy really genuinely wanted to help the poor people, Reinhold Dirks [Head of Fundación Visión]. That's how that idea came up and Martin [Burt, head of Fundación Paraguaya] was willing, Reinhold was willing... we were trying to create a win-win model.

It might be the case the "foreignness" of Fundación Visión relative to Aravind actually spurred effort on the part of both parties to make the relationship work. That is, due to the potential for miscommunication organizational members actually made a greater effort to communicate effectively with their counterparts from across the world.

\section{Discussion}

A number of scholars have called for research which highlights the distinctive nature of organizational processes in a social entrepreneurial context, where multiple institutional logics operate (Battilana and Lee 2014; Pache and Santos 2010; Dees et al. 2004), and in particular for those areas outside of metropolitan centers which are less conducive to developing thriving social enterprise ecosystems (Jia and Desa 2018). The present research addresses these calls by examining how social enterprises manage partnerships with other organizations that have related or distinct guiding logics and, ultimately, how social enterprises use partnerships to transfer innovations across geographic boundaries. In this sense, the article interrogates knowledge transfer processes across inequities of power, resources, market access, and governance (Wijers 2019; Piatti and Dwiartama 2016; Doering 2016; Seelos and Mair 2010; Hodge and Greve 2007), though it explores these issues in the relatively unique context of a "South-toSouth" collaboration between organizations in India and in Paraguay. The article makes three contributions.

First, this work helps to illuminate the extent to which organizations which operate in environments with multiple institutional demands and with multi-dimensional goals manage their organizational processes and behaviors in order to achieve increased impact nationally and internationally (Dacin et al 2010). In particular, by illuminating the heretofore under-examined spiritual logic, it provides opportunities for researchers to develop these concepts further. Recent work in institutional theory has pointed to the relatively unexplored domain of religion in the study of modern organizations, and in the domain of international development in particular (Gümüsay 2017; Tracey 2012; Parboteeah et al 2009; Ver Beek 2000). For instance, Gümüsay (2017) argues that a heterogeneous intra-institutional religious logic may help scholars to theorize across different contexts about the impact of religion on organizational practices and values. While this macro-level focus is welcome, the present study goes beyond such broad-level constructs to illuminate the role that a spiritual logic may play in facilitating the transfer of ideas and practices between organizations, even when they are located at different ends of the earth. Both Aravind and Fundación Visión had prior collaboration experience with other spiritually-oriented hospitals. Where there were potential pitfalls due to language barriers, Aravind sent staff to work extensively on-site to ensure that practices were transferred, and this resulted in the successful transfer of their patient care and patient management practices to Fundación Visión.

Beyond this, what is particularly noteworthy about the partnership is the fact that while Fundación Visión is a 
Christian organization, Aravind's spiritual dimension is rooted in Hinduism. Nevertheless, despite vastly different religious traditions, with one organization rooted in Western, Christian, traditions even if located in a developing country setting, and the other linked to an ancient "Eastern" religion, the organizations' underlying commitment to a "higher power" served as an important point of commonality which seemed to have facilitated their collaboration. Importantly, such a focus on common values between Aravind and Fundación Visión links to the "old institutionalism" idea that values and norms, versus scripts and other taken-for-granted processes as prescribed by neo-institutional theory, can serve as a primary guide for organizational action (Gehman 2020; Gümüsay 2017; Tracey 2012; Dorado 2006). This values turn in the study of institutions can be linked to the recent work of Friedland, who argues for greater focus on "the internal institutional order" of organizational actions as opposed to the "external conditions of their possibility" (2013). Fundamentally, the notion of "internal institutional order" links to the idea that values are embedded in an organization's practices (Klein Jr. 2015), a notion that this study seemingly substantiates in its exploration of organizational practices focused on care for patients as constituted by spiritual organizations such as Aravind and Fundación Visión. In these two hospital systems, the act of delivering eye care is intimately linked to the idea of a "higher power" and serving humanity as confirmed by a range of informants, organizational documents, and artifacts reflecting the influence of the Divine in structuring organizational action. What this study didn't do, however, is examine how the distinct religious traditions underlying the two principal organizations in this study, Hinduism and Christianity, differ in the ways that they influenced Aravind and Fundación Visión, respectively. Future research might explore these differences (Gümüsay 2017; Peifer 2014; Ver Beek 2000).

A second contribution of this paper is to highlight the tactics used by source firms to manage knowledge transfer partnerships with geographically distant partners that are operating in contexts very different to their own. A number of recent studies suggest that different institutional logics guide organizational behavior by providing specific scripts for action and by establishing core principles for organizing activities and channeling interests (Ahmadsimab and Chowdhury 2019; Ebrahim et al. 2014; Battilana and Dorado 2010). These studies provide little insight into the role played by divergent or convergent social logics on the unfolding of a partnership. Because values determine how partnership goals may be accomplished, this is an area of both theoretical and practical concern. For organizations with social goals, partnership is a means to "create social value" and indeed to spread the organization's key values to other organizations and locales. The organizational field plays a major role in shaping these values and the nature of the partnership (DiMaggio and Powell 1983; Friedland and Alford 1991; Thornton and Ocasio 1999). Alignment of partner social enterprises' values may thus facilitie interorganizational collaboration. When alignment isn't there, however, cultural and institutional factors become more important in determining the direction and success of a partnership (Palis 2006), and bricolage mechanisms (Desa 2012; Baker and Nelson 2005) have the potential to gain heightened importance.

For instance, while Fundación Visión entered into the partnership initially to gain access to new technologies and resources related to eye care delivery and process management, they nevertheless encountered difficulties vis-à-vis their cooperation with Fundación Paraguaya, their in-country (local) partner. Specifically, these difficulties stemmed from divergent perceptions relating to efficiency with respect to their vision camps operated distant rural areas using Fundación Paraguaya's networks but which combined both organizations' personnel. In addition, Fundación Paraguaya staff members were "disappointed" with the approach of Fundación Visión towards revenue-generating operations such as the financing of different surgeries. Here, the strong economic logic driving the microfinance organization, Fundación Paraguaya, came into conflict with the weaker economic logic of the eye hospital. Thus, what emerged from the rich case data which constitute this study is that the form of inter-organizational partnership is influenced by the extent to which the source organization manages to balance its multiple logics with those of its partners. While the balance between the two hospital systems was maintained via a strong spiritual logic alignment, differences in the prioritization of the economic logic between Fundación Visión and its in-country partner, Fundación Paraguya, speak to the challenges encountered between organizations which may be operating even in the same local context when their values are not aligned (Bacq and Janssen 2011; Friedland 2013; Klein Jr. 2015; Jia et al 2015).

Building on this second contribution, by situating institutional complexity research in an inter-organizational setting, this study also begins to unpack the processes which emerge when the logics of different organizations have to be simultaneously considered. In doing this, it addresses the following questions: Are these mechanisms indeed different from the traditional knowledge transfer mechanisms studied by organizational scholars? How do partners in a dyadic transfer relationship coordinate their efforts and to what extent to they ensure the fidelity of the innovation is maintained across settings (Ansari et al. 2010)?

By answering these questions, scholars may get closer to an understanding of institutional logics as strategic resources as proposed by Durand et al. (2013); this 
promising line of inquiry may have much do contribute to the ways in which the logics of different organizations interact in an inter-organizational context. Additionally, the study advances knowledge of institutional bricolage mechanisms (Desa 2012; Clough et al. 2019) by linking these processes to settings where a dyadic transfer relationship has to be taken into account. While institutional bricolage mechanisms may enable a search for practical solutions in the social entrepreneurship setting (Desa and Basu 2013), clashes between institutional logics may also hinder the implementation of such solutions when two or more social enterprise partners are involved.

Third, and finally, this research contributes to the emerging literature on "scaling" entrepreneurial innovations in social settings (Seelos and Mair 2017; Desa and Koch 2014; Chowdhury and Santos 2010; Bloom and Chatterji 2009). It does this by: (1) introducing the concept of "innovation fidelity" as a mechanism for managing the transfer process; and (2) by offering possible a view of "scaling" solutions in the social sector which takes into account the notion of logics alignment between partner organizations. With respect to the former, this study highlights how source social enterprises may use refer to the maintenance of the core features of a focal social innovation to manage partners during the transfer process. Innovation fidelity thus relies on using inter-related tactics related to the underlying balance between multiple institutional logics, and has implications in terms of convergent (matching) and divergent (non-matching) social logics in the context of urban-rural transfer settings. Such tactics include including bargaining with managers at the target organization to adopt practices and techniques developed by the source entrepreneur, and emphasizing the principles underlying the impact of the social innovation being transferred. Ultimately, source organizations attempt to maintain innovation fidelity to ensure that the success of the original model and innovation in its new locale.

Where the notion of scaling solutions in the social sector links with values is in the degree of alignment between logics. For instance, alignment vis-à-vis the spiritual logic between Aravind and Fundación Visión, between the source and the target organization, helped to facilitate the process of maintaining innovation fidelity and, ultimately, the scaling of Aravind's model of delivering eye care. This was noted by managers at both organizations in terms of how organizing principles (such as discipline) were linked to the values that the organizations shared. On the other hand, attempts to maintain innovation fidelity may be less successful when logics are mis-aligned. This situation was apparent in the conflict which emerged between Fundación Paraguaya and Fundación Visión vis-à-vis the vision camps example referenced above, wherein divergent perceptions, rooted in different levels of strength (strong vs. weak) of the economic logic at the two organizations, relating to efficiency and revenue generation led to tensions between the two organizations.

With respect to the broader debate on scaling in the social sector, much discussion has focused on "scaling organizations" as the primary means to expand the scope and reach of innovations developed by social entrepreneurs. For instance, Desa and Koch (2014) suggest three underlying requirements for scaling a venture across regions: compatibility of the social innovation, a market penetration strategy, and a design for affordability. Whereas the affordable design aspect and compatibility of the eye care services delivered by Fundación Visión and Aravind was a primary driver for the development of the partnership, Fundaction Visión had to "make do" (Baker and Nelson 2005) with the resources available to it in Paraguay in terms of delivering its services to under-served rural markets in Paraguay.

In particular, the on-the-ground partnership between Fundación Visión and Fundación Paraguay allowed the former organization to utilize and country-wide network developed for the microfinance context to access greater numbers of potential patients for its eye care services. While there were clashes with respect to the social motivation of Fundación Paraguaya's approach, which sought to promote microenterprise approaches to addressing poverty (Doering 2016), versus the more spiritually-grounded social motivation of Fundación Visión, ultimately this "making do" with available resources allowed the expansion of Aravind's approach to delivering eye care services to Paraguay. In this sense, by highlighting the possibility of instead "scaling solutions" (Dees et al 2004) through inter-organizational partnership as a means to achieve similar impact, the study puts forward novel approaches that organizations may undertake to address the issue of increased impact.

Finally, in addition to the theoretical contributions highlighted, the study also has practical implications for program managers, consultants and other actors working with social enterprises to scale the impact of their innovations. Recent work by the psychologist Jonathan Haidt (Treviño et al. 2017; Haidt and Treviño 2017) highlights the importance of developing and strengthening ethical organizational cultures as a way to deal with conflicting sets of foundational beliefs, including divergent political beliefs. The present study, by how examining varying social motivations (emerging from varied social logics) can manifest as tensions or conflicts in partnerships, builds on Haidt's notions by providing a basis for developing mechanisms for resolving these organizational tensions as they emerge in practice. For instance, it defines some of the tactics used by social entrepreneurs to manage the scaling of social innovations via partnering with other social enterprises (e.g., maintaining innovation fidelity). While these tactics may be less efficacious when values are not aligned, negotiating in good faith with partners may result in a positive outcome that both parties can live with. 
As the world deals with the current global pandemic of covid-19, two final practical implications from this study may be particularly relevant. First, managers must understand the importance of modifying practices to fit the reality of contextual conditions where a partner (target) organization is located. While this study took into account the unique resource constraints encountered by organizations seeking to expand their social impact to rural settings, in a covid19-affected world those constraints could well apply to the urban areas which have been hardest hit by the pandemic. Second, in the context of the pandemic, the issue of value alignments and mis-alignments has played out on a global scale. One short illustration of this phenomenon can be seen in the relative willingness to wear face masks as a preventive measure. In countries such as Taiwan and South Korea, universal acceptance of masks (values alignment) has led, up to this point, relatively rapid declines in infection rates and overall disease burden. In contrast, in countries where mask wearing has been contested (values mis-alignment), infection rates have taken longer to decline (Taleb 2020).

Acknowledgements I thank the guest editors of the special issue, Geoffrey Desa and Xiangping Jia, as well as three anonymous reviewers for their guidance during the review process. I also thank Filipe Santos, Anca Metiu, Ignasi Martí, and Wim van Lent for their comments on earlier versions of this paper. Finally, I am indebted to the social enterprises discussed in this article for the access which allowed me to complete this project.

\section{Appendix}

\section{Interview guide}

\section{Introduction}

1. Background of researcher. Offer thanks for agreeing to interview.

2. Research Purpose To investigate how organizations scale-up innovations through transfer to other organizations.

3. Research Approach I am tracking the transfer of innovations by social organizations to partners and analyzing the underlying decisions involved in this process and the rationale.

4. I want to get as broad a perspective of [SOURCE ENTREPRENEUR] as possible, and I one way to do this I think is to speak with people at all levels of the organization. I'd like you to be as free and frank as possible with your answers, but do tell me if any particular remarks might be problematic, etc.
5. I usually transcribe all the interviews for my research-it helps me be more attentive to research during our talk. Do you mind if I record our conversation (turn voice recorder on).

6. How much time do we have? (Usually $60 \mathrm{~min}-90 \mathrm{~min}$ )

\section{General background and personal information}

I would like to start by betting a broad picture of your personal background.

1. Please tell me about your role at [SOURCE ENTREPRENEUR]? Specifically, can you tell me about what your position entails and which areas are under your responsibility? (For the Founder / President: Has your role evolved over the years? How and why? What is your general management philosophy?)

2. Who do you see as the most important people in [SOURCE ENTREPRENEUR]? Could you please give me at least two or three adjectives to describe them?

3. Please summarize the strategy of [SOURCE ENTREPRENEUR] in impacting society and improving the lives of people. How do you think this strategy came about? How is it different from the strategies used by other organizations in your area? How is it the same?

\section{The innovation}

Description:

Source unit:

Target unit:

1. The transfer of this innovation from [SOURCE ENTREPRENEUR] to [TARGET ORGANIZATION]? was:

a. Mandated by top management

b. Strongly encouraged

c. Favored

d. Optional

e. Entirely spontaneous

2. Who, in your opinion, initiated the transfer of this innovation from [SOURCE ENTREPRENEUR] to [TARGET ORGANIZATION]? (tick one or more)?
a. Source
b. Target
c. Funding agency
d. Government body
e. Beneficiaries (villagers)
f. Other 
3. What was your role in this process? How much of your time did you spend working on the [TARGET ORGANIZATION]? staff (ask for percentage)? Did you go to [TARGET ORGANIZATION]?? How many times? When?

4. What are the elements of this innovation? Which is the most important (i.e., the innovation wouldn't work without it)? What has been transferred to [TARGET ORGANIZATION]?-whole or part of the innovation? Why? How might this innovation be applicable to other contexts?

5. Was this innovation changed for [TARGET ORGANIZATION]? in some way vs. how it was done at [SOURCE ENTREPRENEUR] originally? How so?

6. I'd like to establish a chronology of this innovation. When was it developed? Can you tell me how it was developed within your organization? When did you feel you had made the desired impact in your local area? When was the decision to expand beyond your local area made?

7. How did you come to select [TARGET ORGANIZATION]? as a partner for the transfer of this technology? Please describe this process for me.

8. On a scale of 1 to 5 , how well do you thing the transfer process has been going? Are the villagers at the pilot [TARGET ORGANIZATION]? site using this technology per your conversations with [TARGET ORGANIZATION]??

9. What do you think will be the most important determinant of whether the transfer of this technology to [TARGET ORGANIZATION]? is successful?

10. What are the greatest challenges you've faced during the scaling-up process? Have you encountered different challenges in your local area versus expanding to areas further away?

11. Reflecting back on the transfer of sanitation technology between [SOURCE ENTREPRENEUR] and [TARGET ORGANIZATION]?, what would have been the single most important action to facilitate the transfer.

\section{Mission and values}

1. Does [SOURCE ENTREPRENEUR] have a precise Visión about how to conduct social change? If so, what do you think it is?

2. What values drive [SOURCE ENTREPRENEUR]? Have these changed over time?

3. How would you describe the culture of [SOURCE ENTREPRENEUR]? What is the guiding force behind the organization's actions? Social mission? Science?

\section{Organizational evolution (top executives only)}

1. Imagine that you're writing a history of [SOURCE ENTREPRENEUR]. Tell me what you want to write. What are the major changes the organization has faced? Note: Follow story, be clear about time-line, keeping in mind issues of internal and external identity.

2. In 10 years, where do you see [SOURCE ENTREPRENEUR]? What will [SOURCE ENTREPRENEUR] have accomplished during this period?

3. What was the founding mission of [SOURCE ENTREPRENEUR]? Is this still the mission of the organization? If not, what has changed?

\section{Documents to request}

- Annual Reports

- Financial Reports

- Strategic planning documents, past and present

- Organizational chart Number of employees, number of departments, change over time

- External media coverage of organization-articles, web sites, mentions in reports, etc.

Demographic, health, and other relevant data for geographic areas served by the organization (e.g., at the district, town, village levels)

\section{References}

Ahmadsimab, A., and I. Chowdhury. 2019. Managing tensions and divergent institutional logics in firm-NPO partnerships. Journal of Business Ethics. https://doi.org/10.1007/s10551-019-04265-x.

Ansari, S., P.C. Fiss, and E.J. Zajac. 2010. Made to fit: How practices vary as they diffuse. Academy of Management Review 35: 67-92.

Arjaliès, D.L., and R. Durand. 2019. Product categories as judgment devices: The moral awakening of the investment industry. Organization Science 30: 885-911.

Bacq, S., and F. Janssen. 2011. The multiple faces of social entrepreneurship: A review of definitional issues based on geographical and thematic criteria. Entrepreneurship \& Regional Development 23: 373-403.

Baker, T., and R.E. Nelson. 2005. Creating something from nothing: Resource construction through entrepreneurial bricolage. Administrative Science Quarterly 50: 329-366.

Barraket, J., R. Eversole, B. Luke, and S. Barth. 2018. Resourcefulness of locally-oriented social enterprises: Implications for rural community development. Journal of Rural Studies. https://doi. org/10.1016/j.jrurstud.2017.12.031.

Battilana, J., and S. Dorado. 2010. Building sustainable hybrid organizations: The case of commercial microfinance organizations. Academy of Management Journal 53: 1419-1440.

Battilana, J., and M. Lee. 2014. Advancing research on hybrid organizing: Insights from the study of social enterprises. Academy of Management Annals 8: 397-441. 
Bishop, S., and J. Waring. 2016. Becoming hybrid: The negotiated order on the front line of public-private partnerships. Human Relations 69: 1937-1958.

Bloom, P.N., and A.K. Chatterji. 2009. Scaling social entrepreneurial impact. California Management Review 51: 114-132.

Boxenbaum, E., and J. Battilana. 2005. Importation as innovation: Transposing managerial practices across fields. Strategic Organization 3: 355-383.

Chowdhury, I. 2015. Resilience and social enterprise: The case of Aravind eye care system. In Summit on resilience II: The next storm, ed. J. Ryan, 19-26. New York: Pace University.

Chowdhury, I. 2019. Social entrepreneurship, water supply, and resilience: Lessons from the sanitation sector. Journal of Environmental Studies and Sciences 9: 327-339.

Chowdhury, I., and F. Santos. 2010. Scaling social innovations: The case of Gram Vikas. In Scaling social impact: New thinking, ed. P. Bloom and E. Skloot, 147-168. New York: Palgrave Macmillan.

Clough, D.R., T. Pan Fang, B. Vissa, and A. Wu. 2019. Turing lead into gold: How do entrepreneurs mobilize resources to exploit opportunities. Academy of Management Annals 13: 240-271.

Czarniawska, B., and G. Sevón. 1996. Travels of ideas. In Translating organizational change, ed. B. Czarniawska and G. Sevón, 13-48. Berlin: de Gruyter.

Dacin, P.A., M.T. Dacin, and M. Matear. 2010. Social entrepreneurship: Why we don't need a new theory and how we move forward from here. Academy of Management Perspectives 24: 37-57.

Dees, J.G., B.B. Anderson, and J. Wei-Skillern. 2004. Scaling social innovation: Strategies for spreading social innovations. Stanford Social Innovation Review 1: 34-43.

Desa, G. 2012. Resource mobilization in international social entrepreneurship: Bricolage as a mechanism of institutional transformation. Entrepreneurship Theory and Practice 36: 727-751.

Desa, G., and S. Basu. 2013. Optimization or bricolage? Overcoming resource constraints in global social entrepreneurship. Strategic Entrepreneurship Journal 7: 26-49.

Desa, G., and J.L. Koch. 2014. Scaling social impact: Building sustainable social ventures at the base-of-thepyramid. Journal of Social Entrepreneurship 5: 146-174.

Di Domenico, D., H. Haugh, and P. Tracey. 2010. Social bricolage: Theorizing social value creation in social enterprises. Entrepreneurship Theory and Practice 34: 681-703.

DiMaggio, P., and W. Powell. 1983. The iron cage revisited: Institutional isomorphism and collective rationality in organizational fields. American Sociological Review 48: 147-160.

Doering, L. 2016. Necessity is the mother of isomorphism: Poverty and market creativity in Panama. Sociology of Development 2: $235-264$.

Dorado, S. 2006. Social entrepreneurial ventures: Different values so different processes of creation, no? Journal of Developmental Entrepreneurship 11: 1-24.

Durand, R., B. Szostak, J. Jourdan, and P.H. Thornton. 2013. Institutional logics as strategic resources. In Institutional logics in Action, Part A, ed. M. Lounsbury and E. Boxenbaum, 165-201. Bingley: Emerald Group Publishing Limited.

Ebrahim, A., J. Battilana, and J. Mair. 2014. The governance of social enterprises: Mission drift and accountability challenges in hybrid organizations. Research in Organizational Behavior 34: 81-100.

Fiol, C.M., M.G. Pratt, and E.J. O'Connor. 2009. Managing intractable identity conflicts. Academy of Management Review 34: 32-55.

Fisher, G. 2012. Effectuation, causation, and bricolage: A behavioral comparison of emerging theories in entrepreneurship research. Entrepreneurship Theory and Practice 36: 1019-1051.

Friedland, R. 2013. God, love, and other good reasons for practice: Thinking through institutional logics. In Institutional logics in action, part A, ed. M. Lounsbury, 25-50. New York: Emerald Group Publishing Limited.
Friedland, R., and R.R. Alford. 1991. Bringing society back in: Symbols, practices, and institutional contradictions. In The new institutionalism in organizational analysis, ed. W. Powell and P.D. Maggio, 232-266. Chicago: University of Chicago Press.

Gehman, J. 2020. Searching for values in practice-driven institutionalism: Practice theory, institutional logics, and values work. Research in the Sociology of Organizations.

Glaser, B.G., and A.L. Strauss. 1967. The discovery of grounded theory: Strategies for qualitative research. Chicago, IL: Aldine Publishing Company.

Greenwood, R., M. Raynard, F. Kodeih, E. Micelotta, and M. Lounsbury. 2011. Institutional complexity and organizational responses. Academy of Management Annals 5: 317-371.

Gümüsay, A.A. 2017. The potential for plurality and the prevalence of the religious institutional logic. Business \& Society. https:// doi.org/10.1177/0007650317745634.

Gümüsay, A.A., M. Smets, and T. Morris. 2019. 'God at work': Engaging central and incompatible institutional logics through elastic hybridity. Academy of Management Journal. https://doi. org/10.5465/amj.2016.0481.

Haidt, J., and L. Treviño. 2017. Make business ethics a cumulative science. Nature Human Behavior 1: 1-2.

Horowitz, J.R., and A.M. McGahan. 2019. Collaborating to manage performance trade-offs: How fire departments preserve life and save property. Strategic Management Journal 40: 408-431.

James, H. 2014. A new institutional economics perspective on the relationship among societal values, governance structure and access to rural health care services. Southern Business \& Economic Journal 37: 27-55.

Jia, J., \& Desa, G. 2018. Social entrepreneurship and impact investment in rural-urban transformation: Summary symposium findings. https://sfsu.app.box.com/s/saw022dcfwk0sqtbknplx1919 v7xnywm. Accessed 10 Jan 2019.

Jia, X., H. Luan, J. Huang, and Z. Li. 2015. Comparative analysis of microfinance and formal and informal credit use by farmers in less developed areas of rural China. Development Policy Review 33: 245-263.

Klein Jr., V.H. 2015. Bringing values back in: The limitations of institutional logics and the relevance of dialectical phenomenology. Organization 22 (3): 326-350.

Langley, A. 1999. Strategies for theorizing from process data. Academy of Management Review 24: 691-710.

Lévi-Strauss, C. 1966. The savage mind. Chicago: University of Chicago Press.

Lounsbury, M. 2007. A tale of two cities: Competing logics and practice variation in the professionalizing of mutual funds. Academy of Management Journal 50: 289-307.

Mair, J., and I. Martí. 2006. Social entrepreneurship research: A source of explanation, prediction, and delight. Journal of World Business 41: 36-44.

Mars, M.M., and H.J. Schau. 2017. Institutional entrepreneurship and the negotiation and blending of multiple logics in the Southern Arizona local food system. Agriculture and Human Values 34: 407-422.

McDermott, K., E.C. Kurucz, and B.A. Colbert. 2018. Social entrepreneurial opportunity and active stakeholder participation: Resource mobilization in enterprising conveners of crosssector social partnerships. Journal of Cleaner Production 183: 121-131.

McNamara, P., F. Pazzaglia, and K. Sonpar. 2018. Large-scale events as catalysts for creating mutual dependence between social ventures and resource providers. Journal of Management 44: 470-500.

Miles, M.B., and A.M. Huberman. 1994. Qualitative data analysis, 2nd ed. Thousand Oaks, CA: Sage Publications.

Nirmalan, P.K., J. Katz, A.L. Robin, R. Krishnadas, R. Ramakrishnan, R.D. Thulasiraj, and J. Tielsch. 2004. Utilisation of eye care 
services in rural south India: The Aravind comprehensive eye survey. British Journal of Ophthalmology 88: 1237-1241.

Oliver, C. 1991. Strategic responses to institutional processes. Academy of Management Review 16: 145-179.

Pache, A., and F. Santos. 2013. Inside the hybrid organization: Selective coupling as a response to competing institutional logics. Academy of Management Journal 56: 972-1001.

Pache, A., and F.M. Santos. 2010. When worlds collide: The internal dynamics of organizational responses to conflicting institutional demands. Academy of Management Review 35: 455-476.

Palis, F.G. 2006. The role of culture in farmer learning and technology adoption: A case study of farmer field schools among rice farmers in Luzon, Philippines. Agriculture and Human Values 23: 491-500

Parboteeah, K., M. Hoegl, and J. Cullen. 2009. Religious dimensions and work obligation: A country institutional profile model. Human Relations 62: 119-148.

Peifer, J.L. 2014. The institutional complexity of religious mutual funds: Appreciating the uniqueness of societal logics. Research in the Sociology of Organizations 41: 339-368.

Peifer, J.L., D.R. Johnson, and E.H. Ecklund. 2019. The moral limits of the market: Science commercialization and religious traditions. Journal of Business Ethics 157: 183.

Pratt, M.G. 2009. From the editors: For the lack of a boilerplate: Tips on writing up (and reviewing) qualitative research. Academy of Management Journal 52: 856-862.

Piatti, C., and A. Dwiartama. 2016. From food security to the enactment of change: Introduction to the symposium. Agriculture and Human Values 33: 135-139.

Sahlin-Andersson, K. 1996. Imitating by editing success. The construction of organizational fields and identities. In Translating Organizational Change, ed. B. Czarniawska, and G. Sevón, 69-92. Berlin: de Gruyter.

Saz-Carranza, A., and F. Longo. 2012. Managing competing logics in public-private joint ventures. Public Management Review 14: 331-357.

Seelos, C., and J. Mair. 2017. Innovation and scaling for impact: How successful social enterprises do it. Redwood City: Stanford Business Books.

Seelos, C., \& Mair, J. 2010. Organizational mechanisms of inclusive growth: A critical realist perspective on scaling. IESE Business School Working Paper.

Skelcher, C., and S.R. Smith. 2014. Theorizing hybridity: Institutional logics, complex organizations, and actor identities. Public Administration 93: 433-448.

Smith, B., M. Meyskens, and F. Wilson. 2014. Should we stay or should we go? 'Organizational' relational identity and identification in social venture strategic alliances. Journal of Social Entrepreneurship 5: 295-317.

Suddaby, R. 2006. From the editors: What grounded theory is not. Academy of Management Journal 49: 633-642.

Taleb, N. 2020. The masks masquerade. https://medium.com/incerto/ the-masks-masquerade-7de897b517b7. Accessed 15 June 2020
Thornton, P., and W. Ocasio. 1999. Institutional logics and the historical contingency of power in organizations: Executive succession in the higher education publishing industry 1958-1990. American Journal of Sociology 105: 801-843.

Thornton, P., and W. Ocasio. 2008. Institutional logics. In The sage handbook of organizational institutionalism, ed. R. Greenwood, C. Oliver, R. Suddaby, and K. Sahlin-Andersson, 99-129. New York: Oxford University Press.

Tracey, P. 2012. Religion and organization: A critical review of current trends and future directions. Academy of Management Annals 6: 87-134.

Treviño, L.K., J. Haidt, and A.E. Filabi. 2017. Regulating for ethical culture. Behavioral Science \& Policy 3: 56-70.

van Wijk, J., C. Zietsma, S. Dorado, F.G.A. de Bakker, and I. Martí. 2018. Social innovation: Integrating micro, meso, and macro level insights from institutional theory. Business \& Society. https://doi. org/10.1177/0007650318789104.

Ver Beek, K.A. 2000. Spirituality: A development taboo. Development in Practice 10: 31-43.

Voronov, M., D. De Clercq, and C.R. Hinings. 2013. Institutional complexity and logic engagement: An investigation of Ontario fine wine. Human Relations 66: 1563-1596.

Vurro, C., M.T. Dacin, and F. Perrini. 2010. Institutional antecedents of partnering for social change: How institutional logics shape crosssector social partnerships. Journal of Business Ethics 94: 39-53.

Wijers, G.D.M. 2019. Inequality regimes in Indonesian dairy cooperatives: Understanding institutional barriers to gender equality. Agriculture and Human Values 36: 167.

Wry, T., and J. York. 2017. An identity-based approach to social enterprise. Academy of Management Review 43: 437-460.

Zhao, E. 2014. Mission drift in microfinance: An exploratory empirical approach based on ideal types. Research Methodology in Strategy and Management 9: 77-109.

Publisher's Note Springer Nature remains neutral with regard to jurisdictional claims in published maps and institutional affiliations.

Imran Chowdhury, Ph.D., is the Diana Davis Spencer Chair of Social Entrepreneurship and Associate Professor of Business \& Management at Wheaton College in Norton, Massachusetts (USA). He teaches courses in entrepreneurship, strategic management and international management, and conducts research at the intersection of business and society, encompassing domains such as social entrepreneurship and innovation, corporate social responsibility, philanthropy, and community-focused organizations. He received his Ph.D. from L'École supérieure des sciences économiques et commerciales (ESSEC Business School) in France. 